\title{
Dale Larsen
}

\section{The Friday E-Mail List Or, how I learned to love business students}

A bout a year ago, I was given the task of better integrating myself as a librarian with the College of Business, an area that I had some interest in, but was essentially an outsider. However, on a large commuter campus of around 30,000 students, one could argue these lonely feelings are de rigueur for students and faculty alike, so I wasn't discouraged.

I made contact with a group of faculty who taught the "Writing for Business" class that was required for all business undergraduates. From this meeting and a proposal of some of my teaching ideas, some of the faculty adopted my one-shot class visit to the library in the context of successfully completing their semester-long assignment. The assignment was to make a hypothetical recommendation to a publicly traded company on a particular business practice.

The one-shot classes were a positive experience for me for a variety of reasons, most notably the ability to get a little experience working with business students under my belt. But there was still something missing. It was difficult to build relationships with the students before my single class visit was over.

I received precious little feedback on how effective my instruction sessions were, other than friendly thanks from the faculty. I would say the biggest problem was a lack of time to understand what research problems the students were having in the class through the course of the semester.
An idea came to me right in the middle of teaching a particularly lethargic group of undergrads. The class was at night, off campus, the students had just eaten dinner, their teacher had just left, and they found themselves logged into computers with a high-speed Internet connection (unfiltered).

To an undergraduate in this situation, time had stopped, and the librarian had become a muttering amorphous blob somewhere at the edge of a Facebook page. As an aside, these are the times to innovate and take risks because the stakes are so low they simply won't register on any known scale. Frustrated, I declared that if any student in the class sent me their thesis statement, or even a fuzzy idea of it, that I would send them a "guaranteed scholarly" resource every single Friday for the balance of the semester. All I required was one single e-mail from them requesting this service. As the idea was conceived on a Friday, I imaginatively called it the Friday E-Mail List.

After some trial and error, here's how it works: While introducing yourself to a class, offer your contact information along with the idea that anyone who contacts you via e-mail with a specific subject or thesis will then receive weekly on-topic e-mails. Upon receiving any e-mail contact for the

Dale Larsen is assistant librarian in the education services department of the University of Utah J. Willard Marriott Library, e-mail: dale.larsen@utah.edu

(๑) 2014 Dale Larsen 
first time, there are two things to do: one, add them to a log (I keep mine in Google Docs for easy access), and two, send them a return e-mail thanking them for joining the list and letting them know when to expect their first resource.

Regarding keeping a log, which is necessary, I found a need for the following information: the student's name, the context of his or her search (the class and assignment), the student's e-mail, the original request to join the Friday E-Mail List, and a rough log of when and what you've sent so you don't repeat yourself the following Friday.

Evaluation is important and can be achieved in a number of ways. I have contacted the sponsoring professors who have been the most important key to translating the value of the Friday E-Mail List. I have also instituted online surveys at the end of the semester, which are trickier to get valuable responses from. I also instituted a periodic "feedback loop," where I deliver the usual Friday E-Mail, but with a question asking about the student's paper or any problems the student may be having. The question is a great way to determine whether the students are actually reading your messages, and it's a good way to negotiate future e-mails.

A drawback of doing the Friday E-Mail List is that it does consume time. If you set out every Friday at 2 p.m. to work on the list, depending on your situation, you may find the list impossible to complete by the end of the day. However, if you keep your log with you wherever you go, or post/edit it on an online document sharing space like Google Docs, then you can just chip away at it one or two entries at a time throughout the week. Filling in the gaps as you go and putting them on the log to be e-mailed later is, by far, the most effective way of getting the list done each week.

Just like reference work, answering one or two of the list questions is not something that needs warming up to do, but rather it is easy to just pick up and set down like a crossword puzzle. Using this technique has allowed me to maintain lists of 15 to
20 students, although it is a relief when the semester ends on a really big list.

So you may be asking, Why would I bother doing what is essentially reference work when I'm already busy? On one hand, the outreach and marketing side of things are easy to understand. Librarians visiting classes already achieve this, but the constant help every Friday has actually yielded more "return customers" than any class I've ever taught. This manifests itself in students sending me requests for information or help for classes well after they have completed the writing for business course. I have had comments from several faculty on the popularity of "that librarian," and I've been asked to return or even substitute for other librarians' instruction sessions, too. The list also serves the goals of the College of Business, which has been trying to improve the quality of writing in its students.

The list is an excellent professional development tool. As a relatively new librarian in the subject of Business, I was lost at sea when someone wanted to find information, for example, on the sustainability of baby diapers and what solutions were being offered in industry here in the United States and worldwide. The Friday E-Mail List allowed me to hammer away at this for weeks, and the student and I learned quite a lot together.

The list also forced me to learn how to regularly consult with fellow librarians in Science and Engineering, Fine Arts and Graphic Design, Communications, and so on. One could also argue the list would be helpful in collection development and assessment, staff training, and organizational understanding (in the library or in the college you serve).

As something that started almost accidentally, this idea has blossomed into a seemingly successful venture that could be colored as an embedded librarian tool or an element of a "flipped classroom." The Friday E-Mail list is simple in delivery and natural for any librarian to perform, yet the positive outcomes are quite tangible in myriad ways. 